\title{
Military Expenditure and Economic Growth in Asean-5 Countries
}

\author{
M.T. Hirnissa \\ Department of Economic, Universiti Putra Malaysia \\ 43400 Serdang, Selangor Darul Ehsan, Malaysia \\ Tel: 60-3-8946-7635 E-mail: nissa_tahir16@yahoo.com \\ Muzafar Shah Habibullah (Corresponding author) \\ Department of Economic, Universiti Putra Malaysia \\ 43400 Serdang, Selangor Darul Ehsan, Malaysia \\ Tel: 60-3-8946-7635Ｅ-mail: muzafar@econ.upm.edu.my \\ A.H. Baharom \\ Department of Economic, Universiti Putra Malaysia \\ 43400 Serdang, Selangor Darul Ehsan, Malaysia \\ Tel: 60-3-8946-7751 E-mail: baharom@econ.upm.edu.my
}

\begin{abstract}
In this study we employ the bounds testing procedure suggested by Pesaran (2001) and dynamic OLS (DOLS) proposed by Stock and Watson (1993) to test the robustness of the causal effect and long-run relationships between military expenditure and economic growth in ASEAN-5 countries from the year 1965 to 2006. Generally, our results suggest that: (1) there are only three (Indonesia, Thailand, Singapore) out of five countries analyzed exhibit long-run relationship between military expenditure and economic growth; (2) While for the case of Singapore, the causality is bidirectional, for Indonesia and Thailand it is unidirectional from military expenditure to economic growth; and (3) For the remaining countries, (Malaysia and Philippines), no meaningful relationship could be detected. The results are robust, producing similar results employing both Auto Regressive Distributed Lag (ARDL) and Dynamic Ordinary Least Square (DOLS).
\end{abstract}

Keywords: Military expenditure, Economic growth

\section{Introduction}

The relationship between military expenditure and economic growth has been widely debated among economists. However, there is no specific prediction of the direction of causation between the military expenditure and economic growth. In general, studies have found that military expenditure can influence an economy both positively or negatively. Results are mixed and often contradicting. Military expenditure can affect economic growth through a number of channels. For example, military expenditure can affect an economy either positively as per the finding of Hassan, Waheeduzzaman, and Rahman (2003), through an expansion of aggregate demand or through increase security, and negatively (Deger, 1986) through a crowding out of investment. On top of that, there are findings showing no meaningful relationship as found by Galvin (2003) and Yildirim et al. (2005). In some cases, the results are mixed as found by Kollias et al. (2004) and Dakurah et al. (2000).

Military expenditures can stimulate an economy through the Keynesian multiplier mechanism especially in the period of high unemployment. According to Keynes, expenditure may stimulate growth, i.e. when aggregate expenditure increases, aggregate demand also increases. This will further increase the utilization of capital stock which in turn lead to higher profit and may induce higher investment, thus generating short run multiplier effects and higher growth rates. (Benoit, 1978).

Benoit (1978) further argues that an increase of the military expenditure can promote economic growth by increasing human capital capabilities of the workforce through provision of education, especially in less developed countries where the military industries may provide valuable skill. There may be positive externalities through the development of the military sector on the civilian, for example the development of infrastructure (highway, airport, road and information technology) which can ultimately promote growth. Military expenditure provides protection to the nation citizen by maintaining internal and external security, thus creating positive trade and investment climate for domestic as 
well as foreign investors. Though the finding of this study is interesting, we could not find any other studies supporting it.

On the other hand, adverse growth effects will arise by increasing the military spending. Deger and Smith (1983) argue that an increase of military expenditure can hinder economic growth. Increase in military expenditure will take the best capital equipment and technological innovations for consumption and investment that may be more growth-oriented than military expenditure. Military expenditure can create bottlenecks in a constrained economy. On top of that, it also slows down development through the fostering of a militaristic ideology. Furthermore, military can cause balance of payments problems if hard-earned foreign exchanges are used to purchase arms and defense hardware.

The main concern about the issue of military spending is that, we can see the world continuing to devote large amount of spending to the military sector. Higher military spending tend to correlate with higher economic growth and also as a protection to maintain the peaceful of the world. However, the public differ on this opinion in that the spending will lead to war. Besides, higher taxation needed to finance higher military spending, thus in long run, it will drag the economic growth down. This difference in arguments has led to different opinions on whether military expenditure has either positive or negative impact on economic growth. The intrinsic value of national security is perhaps the most important argument for defense spending. Definitely, national security allows for productive economic activities to be carried out without fear of foreign appropriation. Thus, defense spending is expected to provide national security and subsequently enhance economic growth in the long-run (Ram, 1996).

The objective of this paper is to examine the causal relationship between military expenditure and economic growth in the ASEAN-5 countries namely Malaysia, Indonesia, Singapore, Thailand and Philippines using annual data for the period 1965 to 2006. The paper is organized as follows. In the next section we discuss the trend of military expenditures in ASEAN countries. In section 3 we discuss the review of related literature. In section 4 we present the ARDL bound testing that will be used in this study. In section 5 we report the empirical results and the last section contain our discussion.

\section{Trend of Military Expenditure in ASEAN Countries.}

Military expenditure has been an important component in the fiscal budget of the ASEAN-5 countries (Sipri, various issues). Generally the ratio of military spending to GDP in ASEAN-5 is quite stable. However, as a consequence of financial crisis in 1997, there are significant decreases in military expenditure in year 1998 except for Singapore. Figure 1 shows the trend of military expenditure for ASEAN-5 at constant price (2005) from 1990 to 2006. Among the ASEAN countries, Singapore, despite being the smallest country in term of size; it has the highest level of military spending. Singapore has very capable, modern and well trained ground, air and naval force. National Services introduced in the year 1967 build up the required manpower resources in a relatively quick and cost-effective fashion by providing military education. Her military expenditure has shown a consistently upward trend from 1998 to 2007. As a matter of fact, since 1970, Singapore has allocated an average of 6 percent of its GDP to military expenditure.

As for the case of Thailand, military expenditure is maintained in the range of US\$2000 million per annum since 2000(Sipri, various issues).. For the years prior to 2000, it can be observed that there are fluctuations in the military expenditure pattern. From year 1990 to 1995, military expenditure displays increasing trend but after 1995 it declines until year 2000. It is due to plummeting Thailand's GDP which consequently effected their budgeting, all because the after effect of 1997 financial crises. Since that crisis, Thailand relegates defense spending to a lower priority.

In Malaysia and Indonesia, the spending pattern is almost similar. From year 1990 to 1995 the trend is upward and after 1995, (Sipri, various issues) the military spending in this two countries decreases until year 1998. After year 1998, military expenditure has shown an upward trend but small quantum of increases from year to year until 2006. And for the Philippines, the trend for military spending is maintained from 1990 to 2006.

In general, military expenditure as a percentage of GDP is about 2.4 to 2.6 in Malaysia for the past 15 years. There are some efforts to improve the military forces by the Malaysian government. In early 1990s, Malaysia undertook a major attempt to expand and modernize its armed forces. In the year 2000, the Defense Minister announced a review of national defense and security policy to bring up to date. In early 2004, the Ministry of Defense initiated a compulsory National Services program for the selected secondary school leavers aged seventeen.

Table 1 shows the military expenditure as a percentage of gross domestic products in ASEAN-5 economies. As shown in Table 1, Singapore ranks the highest in the military spending from 1990 to 2005, followed by Malaysia. Philippines ranked $5^{\text {th }}$ has only $1.4 \%$ military expenditure and the ratio decreases to $0.9 \%$ in year 2005 . The main reason for the decrease is that Philippines had energy and financial crises.

\section{Review of Related Literature}

The studies on the nexus between military spending and economic growth have been conducted since the early 1970s. The study on this issue was pioneered by Benoit $(1973,1978)$. He found that there is a positive correlation between 
military expenditure and economic growth for the 44 less-developed countries. Since then, there have been many studies attempting to assess the impact of defense expenditure on economic growth and vice versa. Nevertheless the result on how defense spending influence growth is lack of consensus. Empirical evidence tends to vary across countries and over time, and the results are sensitive to the underlying theoretical framework. Most common findings are that military spending has no significant impact, positive or negative, on economic growth.

Galvin (2003) and Dakurah et al. (2000) examined the case for developing countries. While Yildirim et al. (2005) studied on Middle Eastern countries. As for European Union (EU) a studies were conducted by Kollias et al. (2004), and South Asian Regional Cooperation Council (SAARC) by Hassan et al. (2003).

Deger (1986) found negative relationship between military expenditure and growth in the less developed countries (LDCs), citing that defense expenditure takes resources away from productive investments and fails to mobilize and create additional savings. Other empirical studies that found significant adverse relationship of defense spending on the economy include studies by Smith (1983), Deger and Smith (1983), Deger and Sen (1982, 1983) and Faini et al. (1984).

Dakurah, Davies and Sampath (2000) studied 62 LDCs and found 13 countries showing unidirectional causality from military expenditure to growth; 10 cases from economic growth to military expenditure; 7 countries suggest bidirectional causality and the rest 18 countries displaying no meaningful relationship. Kollias, Naxakis, and Zarangas (2004a) analysis on $15 \mathrm{EU}$ countries also found mixed results in term of causal direction whereby majority of the countries showing unidirectional causality from economic growth to spending expenditure. They conclude that an EU government derives defense expenditure based on the economic performance. In another study, Kollias, Manolas and Paleologou (2004b) investigated the presence and direction of causality issue between growth and military spending focusing in the case of Cyprus covering the period 1964-1999. The empirical results suggest the presence of instantaneous bi-directional causality between the variables involved.

Hassan et al. (2003) examine the impact of the military expenditure on economic growth and FDI covering five of seven South Asian Regional Cooperation Council (SAARC) nations using panel data over the 1980-1999 periods. Interestingly the result suggests positive relationship between military expenditure and economic growth, and thus supporting the view that military expenditure can bring positive impact on growth.

By extending Barro and Sala-i-Martin model to account for the impact of military expenditure on growth for a cross section of countries, Aizenman and Glick (2006) studied the long-run impact of military expenditure on growth. They suggest that military expenditure induced by external threats should increase growth, while military expenditure induced by rent seeking and corruption should reduce growth.

Yildirim and Ocal (2006) examined the issue of arms race between India and Pakistan and its relation to each country's economic growth. They found that there is a unidirectional causal relationship between military expenditure of India and Pakistan. Reitchuler and Loening (2004) studied on Guatemala and they employed Feder-Ram model to determine linear versus non-linear function. They suggest that the linear model show insignificant effect on growth. However conclusion changes when using non-linear model. They found that at low threshold there is positive effect on growth and beyond the threshold, it turns negative. However, defense is less productive than the civilian sector.

Abu-Bader and Abu-Qarn (2003) found negative effect between military burden and economic growth in Egypt, Israel and Syria. They also found that civilian expenditure caused positive economic growth in Israel and Syria. In the context of Asia, Moon and Hyun (1992) found through disaggregated analysis the effect of heavy defense to have entailed negative implications for growth, distribution and economic stability. Chan (1992) suggests that military spending has not been the direct determinant of Taiwan's economic growth despite heavy burden on defense.

The study by Chowdhury (1981) on causal relationship between economic growth and defense spending which covers fifty-five developing countries and by employing the Granger Causality test and found that the relationships between defense spending and economic growth cannot be generalized across the fifty-five developing countries.

The studies on the causal relationship between military expenditure and economic growth in the Southeast Asian nation have been conducted by Frederiksen and LaCivita (1987), Frederiksen (1991) and Frederiksen and McNab (2001). Frederiksen and LaCivita (1987) explore the causality between defense spending and economic growth for the Philippines for the period 1956 to 1982 . They found that causality runs from economic growth to defense spending and not the other way around that had been suggested by Benoit (1978). The study of Frederiksen (1991) on ASEAN-5 plus South Korea suggests mixed results, and the causal relationships differ from country to country. For Singapore and Indonesia the results indicate that defense spending Granger cause economic growth and in Malaysia, economic growth appears to be a determinant of defense spending; while in the case of Thailand, the result suggests a feedback relationship. For the remaining two countries, Philippines and South Korea, no meaningful relationship between defense spending and economic growth was uncovered. On the other hand, Frederiksen and McNab (2001) examine the relationship between defense spending and economic growth for Malaysia. They conclude that defense spending 
Granger cause economic growth in Malaysia. They have extended the time series through 1999 and found that indeed a clear positive relationship exists from defense spending to economic growth.

\section{Methodology}

\subsection{ARDL Approach to Causality Test}

In order to test for causality between military expenditure and economic growth we utilized the autoregressive distributed lag model (ARDL) popularize by Pesaran et al. (2001). The ARDL has numerous advantages. Firstly, the ARDL approach is able to examine the presence of short run as well as long run relationship between the independent variables and the dependent variable. Secondly, the ARDL model takes a sufficient numbers of lags to capture the data generating process in a general to specific modeling framework (Laurenceson and Chai, 2003). Finally, the ARDL approach provides robust result in a small sample size. Since the sample size of our study is 39 , this provides more motivation for this study to adopt this model.

The ARDL unrestricted error correction model (UECM) is shown below:

A.Model 1:

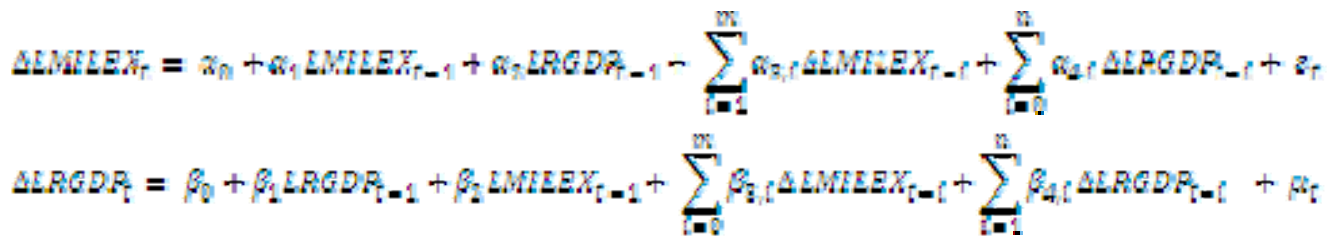

B.Model 2:

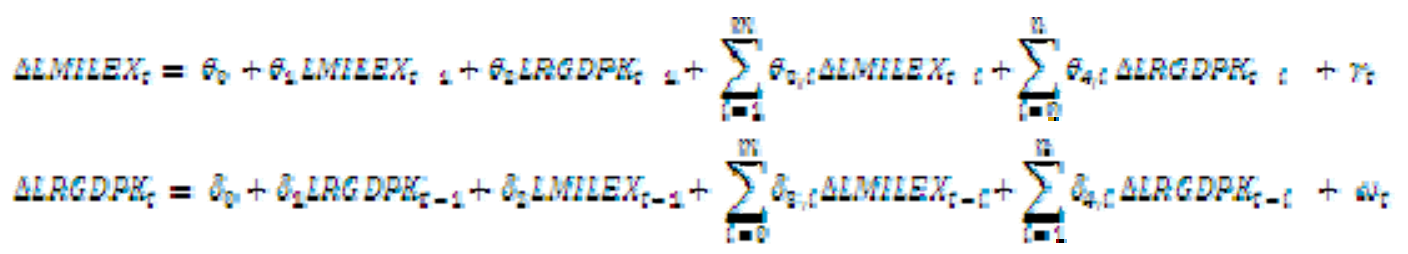

whereby MILEX is the ratio of military expenditure to GDP, RGDP is real GDP, RGDPK is real GDP per capita , $\Delta$ is the first difference operator, $\mathrm{L}$ denote variables in logarithm and $\varepsilon_{t}, u_{t}, \gamma_{\mathrm{t}}$ and $\omega_{\mathrm{t}}$ are serially independent random errors.

To examine the long- run relationship, the bound cointegration test based on $F$-statistic taken from Pesaran et al. (2001) will be used. The long-run relationship between MILEX and RGDP are tested on the following null and alternative hypotheses:

For Equation (1):

$R \sigma: \alpha_{1}=\alpha_{2}=0$ (No long-run relationship), $H_{1}: \alpha_{1}=\alpha_{2} \neq 0$ (A long run relationship).

For Equation (2):

Ka: $\beta_{1}=\beta_{1}=0$ (No long-run relationship), $H_{1}: \beta_{1}=\beta_{2}=0$ (A long run relationship).

For Equation (3):

Ka: $\theta_{1}=\theta_{2}=0$ (No long-run relationship), $R_{2}: \theta_{2} \neq \theta_{2} \neq 0 \quad$ (A long run relationship).

For Equation (4):

$R \sigma: \delta_{1}=\delta_{2}=0$ (No long-run relationship), $H_{1}: \delta_{1}=\delta_{2}=0$ (A long run relationship).

The two asymptotic critical values bound provide a test for cointegration when the independent variables are $I(d)$ (where $0 \leq \mathrm{d} \leq 1)$ : a lower value assuming the regressors are $I(0)$, and an upper value assuming purely $I(1)$ regressors. If the test statistic exceed the upper critical value, we can conclude that a long - run relationship exist regardless of whether the underlying order of integration of variable are zero or one. If the test statistics fall below the lower critical values we cannot reject the null hypothesis of no cointegration. However, if the statistic fall between these two bound, inference would be inconclusive.

In this study we estimate the long -run coefficient by using the dynamic OLS (DOLS) proposed by Stock and Watson (1993). We apply this method because it is more recent and more robust method, particularly for small samples. According to Stock and Watson, DOLS is also a parametric approach for estimating long run equilibrium in a system which may involve variables integrated of different orders but still cointegrated. The DOLS procedure which basically involves regressing any $I(1)$ variables on other $I(1)$ variables, any $I(0)$ variables and leads and lags of the first differences of any $I(1)$ variables. 


\subsection{Description and sources of Data}

The data used in this study are annual data on GDP and Military expenditure based on five ASEAN countries from 1965 to 2006. These countries are Malaysia, Thailand, Singapore, Indonesia and Philippines. MILEX is measured by the military expenditure as a percentage of GDP. This data was obtained from various issues of SIPRI Yearbook and SIPRI online database. For economic growth, it is measured by real GDP (RGDP) and real GDP per capita (RGDPK) which were obtained from World Development Indicator 2004. The data for real GDP and real GDPK is in US\$ and at 2000 constant price. All the data used in the study were transformed into logarithm.

\section{Empirical Results}

Before testing for causality, it is essential to determine the order of integration for each of the country's GDP and military spending series. We conduct the unit root test to determine the order of integration of the series. The Augmented Dickey-Fuller (ADF) tests are reported in Table 2 and Table 3, with series in levels is run with constant and trend, while series in first difference are run with a constant only. The null hypothesis of unit root cannot be rejected at the 5 percent level of significance for the series in levels, while for series in first difference, the null hypothesis of $I(1)$ can be rejected at the 5 percent level of significance. In other words, the five ASEAN countries - MILEX, RGDP and RGDPK series achieve stationarity after first differencing.

Having determined that all series are integrated of order one $I(1)$, we proceed for the testing of cointegration in order to infer Granger causality by using the ARDL bound testing. The cointegration test under this bound test involves the comparison of the critical value and F-statistic. These results are shown in Table 4 and Table 5. When the dependent variable is military expenditure and independent variable is RGDP, two countries namely Indonesia and Singapore display meaningful relationship, as for the other three countries, no significant relationship could be detected. In Panel B of Table 4, when RGDP is the dependent variable, military expenditure is independent, only Singapore shows significant relationship.

In Table 5, when the dependent variable is military expenditure and independent is RGDPK, the results of F-statistic shows that there are 3 countries, namely Indonesia, Thailand and Singapore showing cointegration. However, when RGDPK is the dependent variable, again only Singapore is cointegrated. It can be safely concluded based on the results of this analysis, for the relationship between MILEX and RGDP. Indonesia display a unidirectional causality that runs from RGDP to MILEX, while for the case of Singapore, there are evidence of bidirectional relationship and when RGDPK is used against MILEX, Indonesia and Thailand display unidirectional causality from RGDPK to MILEX while again Singapore shows evidence of bidirectional relationship. As for Malaysia and Philippines, neither model shows any meaningful relationship.

In Table 6 to Table 9, we report the long-run elasticities based on DOLS. In Table 6, the RGDP affect the military expenditure for the case of Singapore and Indonesia with a negative relationship. It is consistent with the previous finding from our ARDL analysis. In Table 7, RGDPK affect the military expenditure for the case of Indonesia, Thailand and Singapore. It is again consistent with the previous finding from ARDL when RGDP and RGDPK are the dependent variables and military expenditure as the regressor, only Singapore are significantly influence the real GDP and real GDPK. So, we can safely conclude that Singapore has a bidirectional causal affect because military expenditure causes real GDP and real GDPK and vice versa. While, for Indonesia and Thailand are unidirectional causal because there are only one way relationship between MILEX and economic growth.

\section{Conclusion}

This study examine the relationship between military expenditure and economic growth for ASEAN-5 countries (Malaysia, Singapore, Thailand, Indonesia and Philippine). In this study we used the autoregressive distributed lag (ARDL) bounds testing procedure to examine the long-run relationship between military expenditure and economic growth using annual data for the period 1965 to 2006.

The result suggest that military expenditure and economics growth for all countries are stationary after first differencing using the unit root test. The cointegration analysis shows there are only 3 out of 5 countries are cointegrated. The presence of long-run negative causality relationship between military expenditure and economic growth is detected for Singapore, Indonesia and Thailand running from RGDP to MILEX. In other word, these countries are having peace dividend. Singapore shows bidirectional causal relationship because military expenditure affects economic growth and vice versa growth also affects military expenditure. While, for Indonesia and Thailand, there are unidirectional causal effect because only economic growth affects military expenditure. The results are in contradiction with Frederiksen (1991) who found unidirectional causality, but from military to growth for the case of Indonesia.

The important implication for this finding is that the respective government should take concern of their economic growth to improve their military expenditure. As for the case of Malaysia and Philippines, no meaningful relationship can be considered as a sign of good governance, or in other words, both these government plan their budget well without causing much impact either positively or negatively on other variables. For Malaysia, the result contradicts the 
finding of Frederiksen (1991) and Frederiksen and McNab (2001). While Frederiksen (1991) found unidirectional causality from economic growth to military spending, Frederiksen and McNab (2001) had different results, which are unidirectional causality from military spending to economic growth.

For the case of Philippines, the results contradict with both Frederiksen and LaCivita (1987) and Benoit (1978). Benoit (1978) found that for the case of the Philippines, unidirectional causality running from defense spending to economic growth. The contradicting finding might be due to different period of study. While our study cover the period 1965-2006, Frederiksen and LaCivita (1987) analyzed data for 1956-1982. At the same time it is not an isolated finding, whereby Frederiksen (1991) found similar results, that is no meaningful relationship between military expenditure and growth in Philippines, contradicting with one of his earlier study.

\section{References}

Aizenman, J. and Glick, R. (2006). Military expenditure, threats and growth, Journal of International Trade and Economic Development, 15(2), 129-155.

Abu-Bader, S. and Abu-Qarn, A.S. (2003). Government expenditure, military spending and economic growth: causality evidence from Egypt, Israel and Syria, Journal of Policy Modelling, 25, 567-583.

Benoit, E. (1978). Growth and defense in LDCs, Economic Development and Cultural Change, 26(2), 271-280.

Biswas, B. and Ram, R. (1986). Military expenditure and economic growth in LDCs: an augmented model and further evidence, Economic Development and Cultural Change, 34(2), 361-372.

Chan, S. (1992). Military burden, economic growth and income inequality: the Taiwan exception, In Steve Chan and Alex (Eds). Defence, Welfare and Growth. New York, Routledge.

Chowdhury, A.R. (1981). A causal analysis of defense spending and economic growth, The Journal of Conflict Resolution, 35(1), 80-97.

Dakurah, A.H., Davies, S.P. and Sampath, R.K. (2000). Defense spending and economic growth in developing countries: a causality analysis, Journal of Policy Modeling, 23, 651-658.

Deger, S. (1986). Economic development and defense expenditure, Economic Development and Culture Change, 35, 179-196.

Deger, S. and Smith, R. (1983). Military expenditure and growth in LDCs, Journal of Conflict Resolution, 27(2), 335-353.

Deger, S. and Sen, S. (1983). Military expenditure, spin-off and economic development, Journal of Development Economics, 13, 67-83.

Faini, R., Annez, P. and Taylor, L. (1984). Defense spending, economic structure and growth: evidence among countries and over time, Economic Development and Culture Change, 32, 487-498.

Frederiksen, P.C. (1991). Economic growth and defense spending: evidence on causality for selected Asian countries, Journal of Philippine Development, 18(1), 131-147.

Frederiksen, P.C. and LaCivita, C.J. (1987). Defense spending and economic growth: time series evidence on causality for the Philippines, 1956-82, Journal of Philippine Development, 14(2), 354-360.

Frederiksen, P.C. and McNab, R. (2001). The Relationship between defence spending and economic growth: a granger causality analysis for Malaysia, 1961 to 1999, STRATEGI: Journal of Strategic Studies on International Relations, 9, 63-71.

Galvin, H. (2003). The impact of defence spending on the economic growth of developing countries: a cross- section study, Defence and Peace Economics, 14(1), 51-59.

Hassan, M.K., Waheeduzzaman, M. and Rahman. A. (2003). Defense expenditure and economic growth in the SAARC countries, The Journal of Political, Social and Economic Studies, 28(3), 275-293.

Joerding, W. (1986). Economic growth and defense spending, Journal of Development Economics, 21, 35-40.

Kalyoncu, H. and Yucel, F. (2006). An analytical approach on defense expenditure and economic growth: the case of Turkey and Greece, Journal of Economic Studies, 33(5), 336-343.

Kollias, C., Naxakis, C. and Zarangas, L. (2004a). Defence spending and growth in Cyprus: a causal analysis, Defence and Peace Economics, 15(3), 299-307.

Kollias, C., Manolas, G. and Paleologou, S.Z. (2004b). Defence expenditure and economic growth in the European Union: a causality analysis, Journal of Policy Modeling, 26, 553-569. 
Laurenceson, J. and Chai, J. C. H. (2003). Financial reform and economic development in China. Chelthenham, Edward Elgar.

Moon, C.I. and Hyun, I.T. (1992). Muddling through security, growth and welfare: the political economy of defense spending in South Korea, In Steve Chan and Alex Mintz(Eds). Defence, Welfare and Growth. New York, Routledge.

Pesaran, M.H., Shin, Y. and Smith, R.J. (2001). Bounds testing approaches to the analysis of level relationships, Journal of Applied Econometrics, 16, 289 - 326.

Ram, R. (1996). Defense expenditure and economic growth. In. K. Hartley and T.Sandler (Eds), Handbook of Defense Economic, 1, 251-273.

Reitschuler, G. and Loening, J.L.(2005). Modelling the defense-growth nexus in Guatemala, World Development, 33(3), 513-526.

SIPRI. SIPRI Yearbook 1975, 1977, 1985, 1990, 1999 and 2006. Oxford, Oxford University Press.

Stock, J.H. and Watson, M. (1993) A simple estimator of cointegration vestors in higher order integrated systems, Econometrica, 61: 783-820

Yildirim, J., Sezgin, S. and Ocal, N. (2005) Military expenditure and economic growth in

Middle Eastern countries: a dynamic panel data analysis, Defence and Peace Economics, 16(4), 283-295.

Yildirim, J. and Ocal, N. (2006). Arms race and economic growth: the case of India and Pakistan.

Defence and Peace Economics, 17, 37-45.

Table 1. Military expenditure as percentage of gross domestic product in ASEAN 5

\begin{tabular}{lcccc}
\hline Year & 1990 & 1995 & 2000 & 2005 \\
\hline Indonesia & 1.8 & 1.6 & 1.0 & 1.2 \\
Thailand & 2.6 & 2.3 & 1.4 & 1.1 \\
Philippines & 1.4 & 1.4 & 1.1 & 0.9 \\
Singapore & 4.9 & 4.4 & 4.7 & 4.7 \\
Malaysia & 2.6 & 2.8 & 1.7 & 2.4 \\
\hline
\end{tabular}

Source: SIPRI year book, various issues.

Table 2. Results of Unit Root Test for Series in Level

\begin{tabular}{|c|c|c|c|c|c|c|}
\hline \multirow[t]{2}{*}{ ASEAN-5 } & \multicolumn{2}{|l|}{ LRGDPK } & \multicolumn{2}{|l|}{ LRGDP } & \multicolumn{2}{|l|}{ LMILEX } \\
\hline & ADF $t$-statistic & Lag & ADF $t$-statistic & Lag & ADF $t$-statistic & Lag \\
\hline \multirow[t]{2}{*}{ Indonesia } & -1.946 & 0 & -0.440 & 0 & -3.309 & 0 \\
\hline & {$[0.61]$} & & {$[0.98]$} & & {$[0.07]$} & \\
\hline Malaysia & -2.082 & 0 & -1.566 & 0 & -2.658 & 0 \\
\hline 0 & {$[0.53]$} & & {$[0.78]$} & & {$[0.25]$} & \\
\hline \multirow[t]{2}{*}{ Philippine } & -2.216 & 1 & -2.554 & 1 & -2.130 & 1 \\
\hline & {$[0.46]$} & & {$[0.30]$} & & {$[0.51]$} & \\
\hline \multirow[t]{2}{*}{ Thailand } & -2.215 & 1 & -1.593 & 1 & -1.471 & 0 \\
\hline & {$[0.46]$} & & {$[0.77]$} & & {$[0.82]$} & \\
\hline \multirow[t]{2}{*}{ Singapore } & -0.245 & 0 & -1.902 & 0 & -3.40 & 2 \\
\hline & {$[0.98]$} & & {$[0.63]$} & & {$[0.06]$} & \\
\hline
\end{tabular}

Notes: Asterisk $\left({ }^{*}\right)$ denotes statistically significant at $5 \%$ level. Figures in square brackets are p-value. 
Table 3. Results of Unit Root Test for Series First in Difference

\begin{tabular}{|c|c|c|c|c|c|c|}
\hline \multirow[t]{2}{*}{ ASEAN-5 } & \multicolumn{2}{|l|}{ LRGDPK } & \multicolumn{2}{|l|}{ LRGDP } & \multicolumn{2}{|l|}{ LMILEX } \\
\hline & ADF $t$-statistic & Lag & ADF $t$-statistic & Lag & ADF $t$-statistic & Lag \\
\hline \multirow[t]{2}{*}{ Indonesia } & -4.427 & 0 & -4.547 & 0 & -5.706 & 0 \\
\hline & {$[0.00]^{*}$} & & {$[0.00]^{*}$} & & {$[0.00]^{*}$} & \\
\hline \multirow[t]{2}{*}{ Malaysia } & -5.283 & 0 & -5.272 & 0 & -6.602 & 0 \\
\hline & {$[0.00]^{*}$} & & {$[0.00]^{*}$} & & {$[0.00]^{*}$} & \\
\hline \multirow[t]{2}{*}{ Philippine } & -3.616 & 0 & -3.781 & 1 & -4.943 & 0 \\
\hline & {$[0.00]^{*}$} & & {$[0.00]^{*}$} & & {$[0.00]^{*}$} & \\
\hline \multirow[t]{2}{*}{ Thailand } & -3.764 & 0 & -3.645 & 0 & -4.475 & 0 \\
\hline & {$[0.00]^{*}$} & & {$[0.00]^{*}$} & & {$[0.00]^{*}$} & \\
\hline \multirow[t]{2}{*}{ Singapore } & -4.685 & 2 & -3.898 & 0 & -7.81 & 1 \\
\hline & {$[0.00]^{*}$} & & {$[0.00]^{*}$} & & {$[0.00]^{*}$} & \\
\hline
\end{tabular}

Notes: Asterisk $(*)$ denotes statistically significant at $5 \%$ level. Figures in square brackets are p-value.

Table 4. Bounds Test for Cointegration Analysis Based on the Equation 6 and Equation 8

Panel A

Dependent variable LMILEX, Independent variable LRGDP

\begin{tabular}{lll}
\hline Critical value & Lower Bound Value & Upper Bound Value \\
\hline $5 \%$ & 3.937 & 4.523 \\
\hline
\end{tabular}

Computed $F$ - statistic

\begin{tabular}{ll}
\hline Countries & $F$-Statistic \\
\hline Indonesia & $15.224^{*}$ \\
Malaysia & 3.0991 \\
Philippine & 1.1772 \\
Thailand & 4.0662 \\
Singapore & $25.189^{*}$ \\
\hline
\end{tabular}

Panel B

Dependent variable LRGDP, Independent variable LMILEX

\begin{tabular}{lll}
\hline Critical value & Lower Bound Value & Upper Bound Value \\
\hline $5 \%$ & 3.937 & 4.523 \\
\hline
\end{tabular}


Computed $F$ - statistic

\begin{tabular}{ll}
\hline Countries & $F$-Statistic \\
\hline Indonesia & 2.3821 \\
Malaysia & 0.6314 \\
Philippine & 0.1216 \\
Thailand & 1.1634 \\
Singapore & $10.025^{*}$ \\
\hline
\end{tabular}

Notes: Asterisk $\left({ }^{*}\right)$ denotes statistically significant at $5 \%$ level.

Table 5. Bounds Test for Cointegration Analysis Based on the Equation 7 and Equation 9

Panel A

Dependent variable LMILEX, Independent variable LRGDPK

\begin{tabular}{lll}
\hline Critical value & Lower Bound Value & Upper Bound Value \\
\hline $5 \%$ & 3.937 & 4.523 \\
\hline
\end{tabular}

Computed F- statistic

\begin{tabular}{ll}
\hline Countries & F-Statistic \\
\hline Indonesia & $5.6335^{*}$ \\
Malaysia & 3.4876 \\
Philippine & 1.2858 \\
Thailand & $7.2023^{*}$ \\
Singapore & $18.7371^{*}$ \\
\hline
\end{tabular}

Panel B

Dependent variable LRGDPK, Independent variable LMILEX

\begin{tabular}{lll}
\hline Critical value & Lower Bound Value & Upper Bound Value \\
\hline $5 \%$ & 3.937 & 4.523 \\
\hline
\end{tabular}

Computed F- statistic

\begin{tabular}{ll}
\hline Countries & F-Statistic \\
\hline Indonesia & 1.1235 \\
Malaysia & 0.6039 \\
Philippine & 4.0044 \\
Thailand & 0.0078 \\
Singapore & $7.0262^{*}$ \\
\hline
\end{tabular}

Notes: Asterisk $(*)$ denotes statistically significant at $5 \%$ level 
Table 6. Long - run coefficient based on DOLS

\begin{tabular}{lll}
\hline $\begin{array}{l}\text { Dependent : LMILEX } \\
\text { Independent: LRGDP }\end{array}$ & Indonesia & Singapore \\
\hline Constant & 5.7650 & 3.4220 \\
& $(5.9304)^{*}$ & $(9.5571)^{*}$ \\
LRGDP $_{\mathrm{t}}$ & -0.4673 & -0.1568 \\
& $(-5.7280)^{*}$ & $(-5.2539)^{*}$ \\
$\Delta$ LRGDP $_{\mathrm{t}}$ & 1.3852 & -0.9431 \\
& $(2.4926)^{*}$ & $(-1.7126)^{*}$ \\
$\Delta$ LRGDP $_{\mathrm{t}-1}$ & 2.7106 & -0.3990 \\
& $(4.2995)^{*}$ & $(-0.6831)^{*}$ \\
$\Delta$ LRGDP $_{\mathrm{t}+1}$ & 0.1259 & -0.5570 \\
& $(0.2101)$ & $(-1.5433)^{*}$ \\
\hline
\end{tabular}

Notes: Asterisk (*) denotes statistically significant at 5\% level.

Table 7. Long - run coefficient based on DOLS

\begin{tabular}{llll}
\hline $\begin{array}{l}\text { Dependent : LMILEX } \\
\text { Independent: LRGDPK }\end{array}$ & Indonesia & Thailand & Singapore \\
\hline Constant & 5.3826 & 4.4104 & 2.7661 \\
& $(8.7412)^{*}$ & $(4.4844)^{*}$ & $(8.1835)^{*}$ \\
LRGDP $_{\mathrm{t}}$ & -0.7851 & -0.5252 & -0.1279 \\
& $(-7.8329)^{*}$ & $(-3.8743)^{*}$ & $(-3.6063)^{*}$ \\
$\Delta$ LRGDP $_{t}$ & 0.5813 & 0.2054 & 0.3322 \\
& $(0.6878)$ & $(0.2839)$ & $(0.9941)$ \\
$\Delta$ LRGDP $_{\mathrm{t}-1}$ & 0.2901 & 2.1746 & -0.0920 \\
& $(0.3978)$ & $(3.2226)^{*}$ & $(-0.1561)$ \\
$\Delta$ LRGDP $_{\mathrm{t}+1}$ & 0.9773 & 0.8702 & 0.5070 \\
& $(1.3889)$ & $(1.4306)$ & $(1.1994)$ \\
\hline
\end{tabular}

Notes: Asterisk $(*)$ denotes statistically significant at $5 \%$ level.

Table 8. Long - run coefficient based on DOLS

\begin{tabular}{ll}
\hline $\begin{array}{l}\text { Dependent : LRGDP } \\
\text { Independent: LMILEX }\end{array}$ & Singapore \\
\hline Constant & 16.8607 \\
& $(12.692)^{*}$ \\
LMILEX $_{\mathrm{t}}$ & -3.9289 \\
& $(-5.1127)^{*}$ \\
$\Delta$ LMILEX $_{\mathrm{t}}$ & 0.0286 \\
& $(0.0267)$ \\
& -0.2168 \\
& $(-0.2843)$ \\
& -1.9234 \\
& $(-4.1403)^{*}$ \\
\hline
\end{tabular}

Notes: Asterisk $\left({ }^{*}\right)$ denotes statistically significant at $5 \%$ level. 
Table 9. Long - run coefficient based on DOLS

\begin{tabular}{|c|c|}
\hline $\begin{array}{l}\text { Dependent : LRGDPK } \\
\text { Independent: LMILEX }\end{array}$ & Singapore \\
\hline Constant & $\begin{array}{l}14.5698 \\
(12.989)^{*}\end{array}$ \\
\hline LMILEX $_{\mathrm{t}}$ & $\begin{array}{l}-3.3517 \\
(-5.0419)^{*}\end{array}$ \\
\hline$\Delta$ LMILEX $_{\mathrm{t}}$ & $\begin{array}{l}0.06225 \\
(0.0 .0709)\end{array}$ \\
\hline$\Delta$ LMILEX $_{\mathrm{t}-1}$ & $\begin{array}{l}-0.1741 \\
(-0.2972)\end{array}$ \\
\hline$\Delta$ LMILEX $_{t+1}$ & $\begin{array}{l}-1.7302 \\
(-4.3939) *\end{array}$ \\
\hline
\end{tabular}

Notes: Asterisk (*) denotes statistically significant at 5\% level.

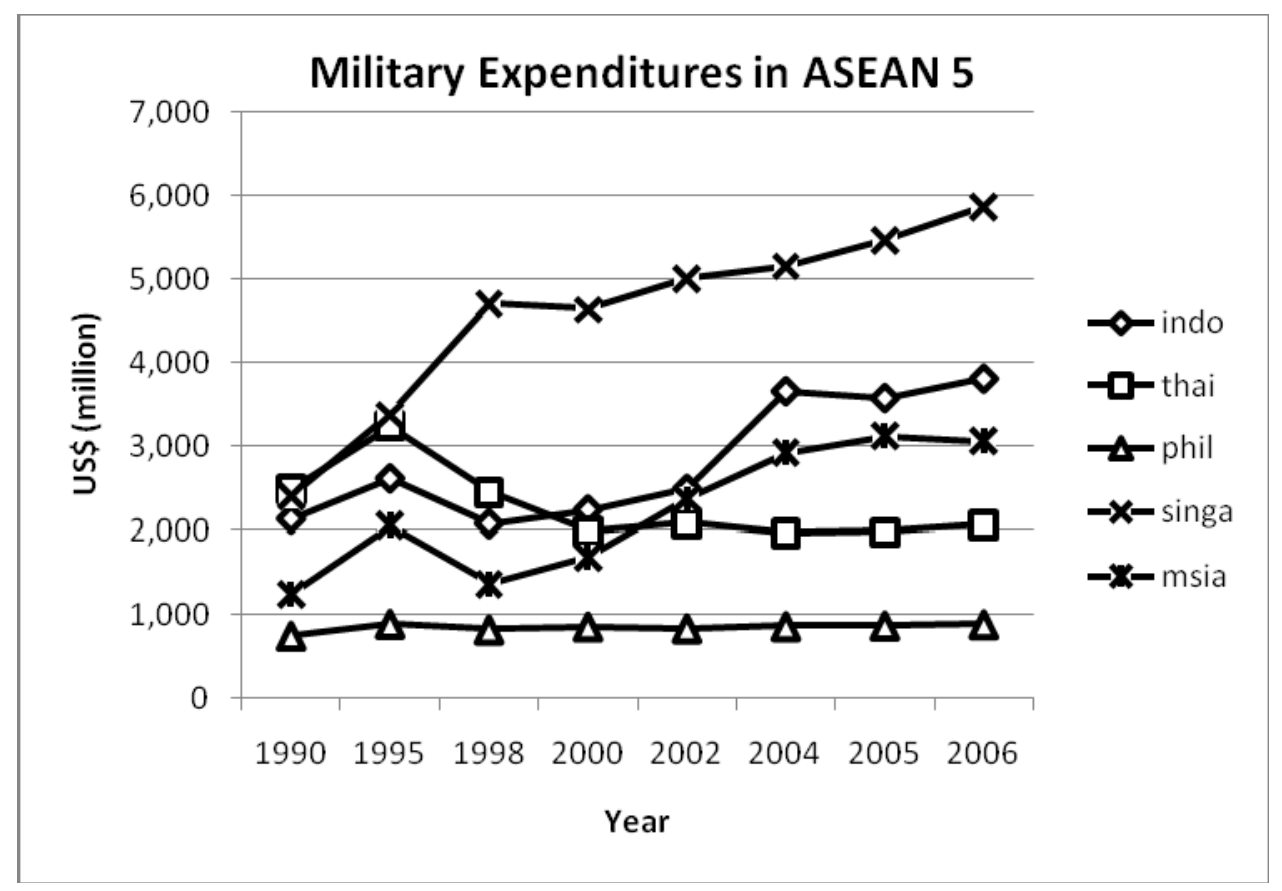

Source: SIPRI year book, various issues.

Figure 1. Military expenditure in ASEAN 5 (constant price 2005) 